\title{
Potential economic impacts of irrigation-water reductions estimated for Sacramento Valley
}

\section{Hyunok Lee $\sqcup$ Daniel Sumner $\square$ Richard Howitt}

This article is drawn from a longer Agricultural lssues Center report, "Economic Impacts of Irrigation Water Cuts in the Sacramento Valley." The full report may be ordered for $\$ 12$ from AIC by calling (530) 752-2320.

\begin{abstract}
In the Sacramento Valley, irrigation water is vital to agriculture and agriculture is vital to local economies. This study investigates these relationships by asking: If surface irrigation water were cut by $25 \%$, what would be the economic impacts on farmers and on communities? The study results indicate that the effects would not be uniform across crops and the eight counties in the Sacramento Valley. In most regions and for most crops, a cut in irrigation water would cause a modest acreage reduction of up to $3 \%$. Overall crop-revenue losses for core regions would total $\$ 8$ million while the loss for the entire Sacramento Valley would be $\$ 11$ million. About $80 \%$ of those losses would take place in poorer counties that depend most heavily on agriculture, and particularly on rice. However, in response to surface-water reductions, farmers and others would mitigate their losses by making adjustments such as conserving water, changing cropping patterns or implementing new technologies.
\end{abstract}

$\mathrm{W}$ e all know that water is important. In particular, water is an essential input for farm production, and California farmers have faced some severe shortages. As water becomes more scarce, farmers act to minimize their losses by adopting water-conserving technologies, shifting from more water-intensive crops to less water-intensive crops, or increasing their reliance on groundwater. These agricultural effects translate through the rest of the economy.

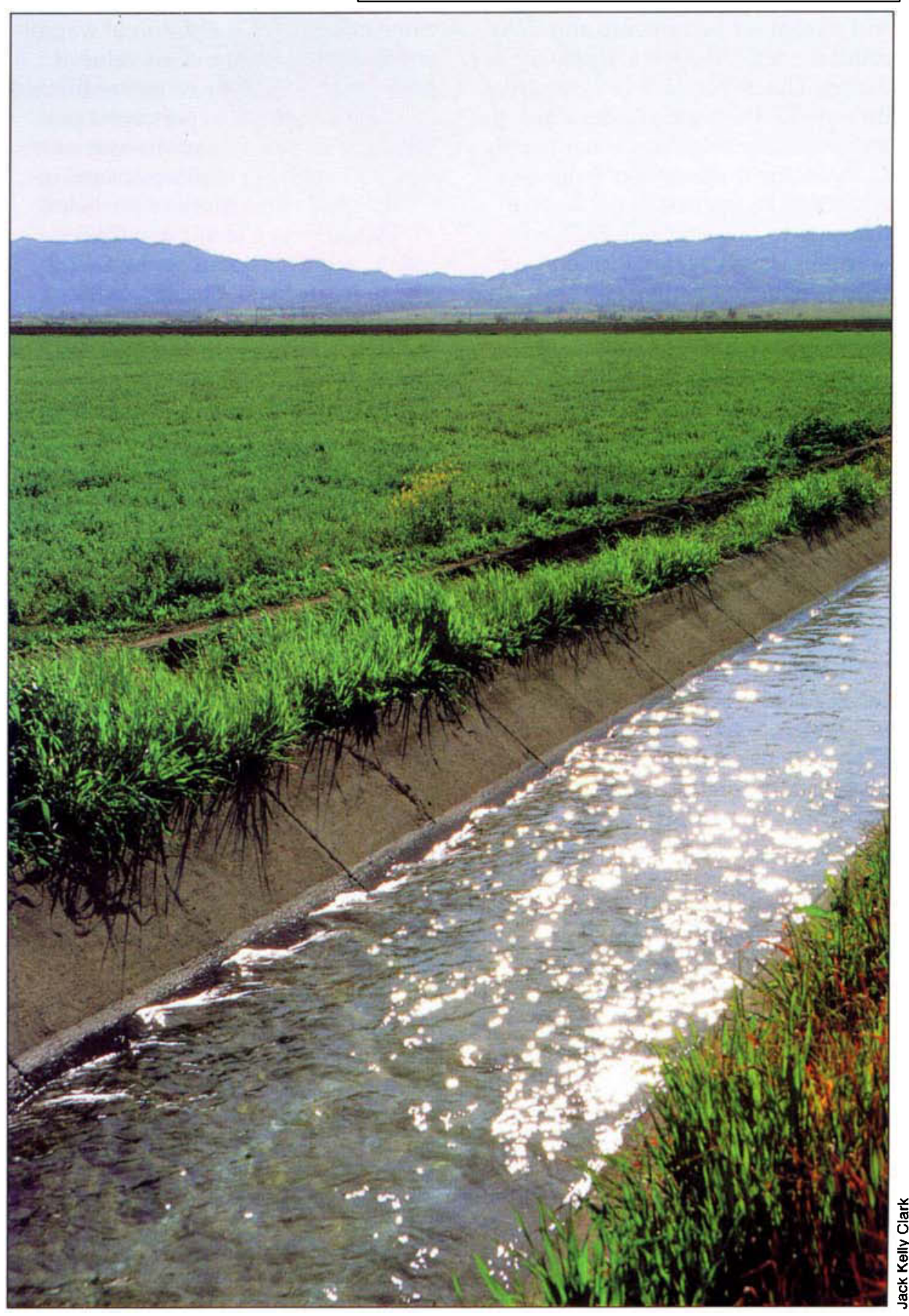

The authors constructed a model to estimate the economic impacts of a $25 \%$ cut in surface irrigation water in the Sacramento Valley. 
This paper analyzes the effects of reduced irrigation water supply on the economies of the Sacramento Valley region. The specific economic variables examined are changes in acre allocations, farm revenues and general economic health of the county, including personal income and employment. The study area includes Butte, Colusa, Glenn, Sacramento, Sutter, Tehama, Yolo and Yuba counties. All these counties have large farming industries and, except for Sacramento and Yolo counties, agriculture is a dominant industry. The importance of agriculture throughout the region underscores the importance of irrigation water supply.

Reducing the supply of irrigation water will be felt first at the farm. In response to less available and probably more costly water, farmers alter their production patterns by adjusting their input use and output production. Fewer acres cropped and lower farm revenue reduce the region's commercial activities and overall county personal income. By calculating these "multiplier effects," we trace the impact of potential irrigation water reductions through to the broader regional economy. Although some calculated impacts, such as on crop acreage and county revenue, are in the single-digit percentages, such declines can have broad economic implications for an entire region.

Our analysis of a hypothetical surface-water reduction utilizes an economic simulation model based on past behavior and profit-seeking by farmers. We consider a scenario of an arbitrarily chosen $25 \%$ cut in surface irrigation water to which one response is a $10 \%$ increase in groundwater use. (Effects on groundwater recharge and quality were not considered.) Finally, the time period considered in our model to adjust from one equilibrium to another is regarded as an intermediate run with the length of 2 to 3 years.

\section{Economy of Sacramento Valley}

The eight Sacramento Valley counties contain almost $7 \%$ of the state's geographic area and $5 \%$ of its population. The population is denser in the two more urban counties, Yolo and Sacramento. These counties also domi- nate the region's economy. Personal income in Sacramento County accounts for $70 \%$ of the Sacramento Valley's total personal income, $\$ 31$ billion, and together with $10 \%$ for Butte County and $9 \%$ for Yolo County, accounts for almost $90 \%$ of the Valley's total personal income. (All our descriptive statistics are, unless mentioned, in 1992 figures.) Colusa and Glenn counties account for only $1 \%$ each, the lowest share. (Personal income of a county is the sum of wages and salaries earned, and the value of products produced by county residents.)

Wide variations in per capita personal income also exist between counties. Although per capita personal incomes of all eight counties are below the state average of $\$ 21,348$, Sacramento and Yolo counties closely follow the state level. The rest of the counties fall between $60 \%$ and $90 \%$ of the state's average. In fact, Tehama and Yuba counties are among the poorest in California with per capita personal incomes ranking 56th and 57 th out of 58 counties.

From the perspective of our study, it is useful to know each county's economic reliance on agriculture. For this measure, the sales value of farm products is calculated as a ratio of personal income in that county. Colusa and Glenn counties, with shares of $54 \%$ and $46 \%$, show the largest relative scale of farm economy and Sacramento County, with $1 \%$, the lowest share. The rest of the counties range between $6 \%$ and $17 \%$. In general, the counties characterized by higher agricultural shares in their personal incomes are the lower per capita personal income counties. Therefore, any disruption of agricultural production may have relatively greater impacts on the economies of counties that rely heavily on agriculture.

\section{Crop production and irrigation}

The Sacramento Valley is endowed with natural water resources. The sur-

TABLE 1. Water use by source and overall water reduction under a $25 \%$ surface-water cut and $10 \%$ maximum groundwater increase

\begin{tabular}{|c|c|c|c|c|c|c|c|}
\hline & & \multicolumn{5}{|c|}{ Water use in 1992} & \multirow{3}{*}{$\begin{array}{c}\text { Overall water } \\
\text { reduction under } \\
\text { hypothetical scenario* }\end{array}$} \\
\hline & & \multirow[b]{2}{*}{ Total water } & \multicolumn{4}{|c|}{ Source } & \\
\hline & & & \multicolumn{2}{|c|}{ Groundwater } & \multicolumn{2}{|c|}{ Surface water } & \\
\hline & & 1,000 aft & 1,000 af & $\%$ share & 1,000 af & $\%$ share & $\%$ \\
\hline Region 2: & Far North & 543 & 396 & 0.73 & 147 & 0.27 & 0.0 \\
\hline Region 3: & Northwest & 1,234 & 402 & 0.33 & 832 & 0.67 & 13.6 \\
\hline Region 4: & Sacramento River & r 958 & 304 & 0.32 & 654 & 0.68 & 13.9 \\
\hline Region 5: & Northeast & 2,040 & 900 & 0.44 & 1,140 & 0.56 & 9.6 \\
\hline Region 6: & Yolo-Solano & 1,029 & 634 & 0.62 & 395 & 0.38 & 3.4 \\
\hline Region 7: & Southeast & 651 & 269 & 0.41 & 382 & 0.59 & 10.5 \\
\hline Region 8: & Sac-San Joaquin & 1,124 & 943 & 0.84 & 181 & 0.16 & 0.0 \\
\hline
\end{tabular}

"Numbers represent the impact of reducing surface water by $25 \%$ and increasing groundwater by $10 \%$. For regions 2 and 8 , zero reduction is shown because $10 \%$ of groundwater is more than $25 \%$ of surface water. †Acre-feet.

Source: DWR 1994, with reported aggregate numbers constructed by authors.

TABLE 2. Acreage response to a $25 \%$ cut in surface-water availability

$\begin{array}{lllllll}\text { Region } 2 & \text { Region } 3 & \text { Region } 4 & \text { Region } 5 & \text { Region } 6 & \text { Region } 7 & \text { Region } 8\end{array}$ Far North Northwest Sac. River Northeast Yolo-Solano Southeast Sac.-S.J.

\begin{tabular}{|c|c|c|c|c|c|c|c|}
\hline & & & & $\%$ & & & \\
\hline Pasture & -1.2 & -27.2 & -9.7 & -0.05 & -13.6 & -6.9 & 0.5 \\
\hline Alfalfa hay & o† & -4 & -0.8 & 1.4 & -2 & -0.7 & 0.3 \\
\hline Sugarbeets & -0.1 & -1 & -0.6 & 0 & -0.6 & -0.3 & 0 \\
\hline Nongrain field crops* & -0.5 & -2.7 & 0.6 & 2.4 & -1.9 & 0.1 & -0.3 \\
\hline Rice & -0.4 & -4 & -3.1 & -1.1 & -2.2 & -1.4 & -0.1 \\
\hline Vegetables & 0 & -0.1 & 0 & 0.1 & -0.1 & 0.04 & 0 \\
\hline Tomatoes & $-\dagger$ & -0.6 & -0.2 & 0.2 & -0.4 & -0.1 & 0.01 \\
\hline Fruits, nuts & -0.6 & -0.3 & -0.1 & 0 & -0.2 & -0.1 & 0 \\
\hline Small grains $\ddagger$ & 一 & -0.6 & 6.3 & 8.5 & -1.9 & 2.4 & -0.4 \\
\hline Subtropical orchards§ & 0 & -0.2 & - & 0.01 & - & - & - \\
\hline Total & -0.4 & -3.1 & 0 & 0 & -2.1 & -2.5 & 0 \\
\hline
\end{tabular}

"Nongrain field crops include field corn, dry beans, oilseeds and miscellaneous hays. †" 0 " means no change; "- " means not relevant or no production.

¥Small grains include wheat, barley, etc.

§ubtropical orchards include kiwifruit and olives. 
rounding mountains and its five major rivers provide abundant water supplies. With these natural advantages, this area has developed major agricultural industries. The Sacramento Valley grows a wide variety of crops including the two most important, rice and orchard crops (almonds, wainuts, stone fruits and olives), as well as wheat, alfalfa hay and vegetables.

Rice. Rice accounts for almost $30 \%$ of the crop acreage and provides $25 \%$ of total crop revenue in the Sacramento Valley. Except for Tehama and Sacramento counties, the Valley is one of the nation's major rice-producing areas with more than $90 \%$ of California's rice land. The rice crop is the single largest irrigation water user in the state, and also the most intense user on a per-acre basis. Rice uses 6.7 acre-feet while some crops such as grapes use as little as 1.3 acre-feet (DWR 1994).

Orchards. Orchards account for $22 \%$ of all crop acreage in the Valley. The economic significance of orchard crops is substantial in all counties. The farm revenue share of orchard crops ranges from $91 \%$ in Tehama County to $16 \%$ in Yolo County, with an overall $44 \%$ share in the Sacramento Valley.

Vegetables. Vegetables, which supply $18 \%$ of the Sacramento Valley's crop revenue, are economically important in Colusa, Yolo and Sutter counties. Yolo County, the most important vegetable producer in the Valley, receives more than $50 \%$ of county crop revenue from vegetable production, primarily from processing tomatoes.

Agriculture in the Sacramento Valley is relatively more irrigationintensive compared with the rest of the state's farmland, accounting for about $30 \%$ of the state's entire agricultural water use over roughly $23 \%$ of its total irrigated crop area. Irrigation water is supplied to the Sacramento Valley mainly from five sources (listed in descending order, by volume):

- Groundwater supplies almost half of the irrigation water in the Sacramento Valley.

- Local surface supplies, including natural rainfall and captured runoff, are the second largest source.

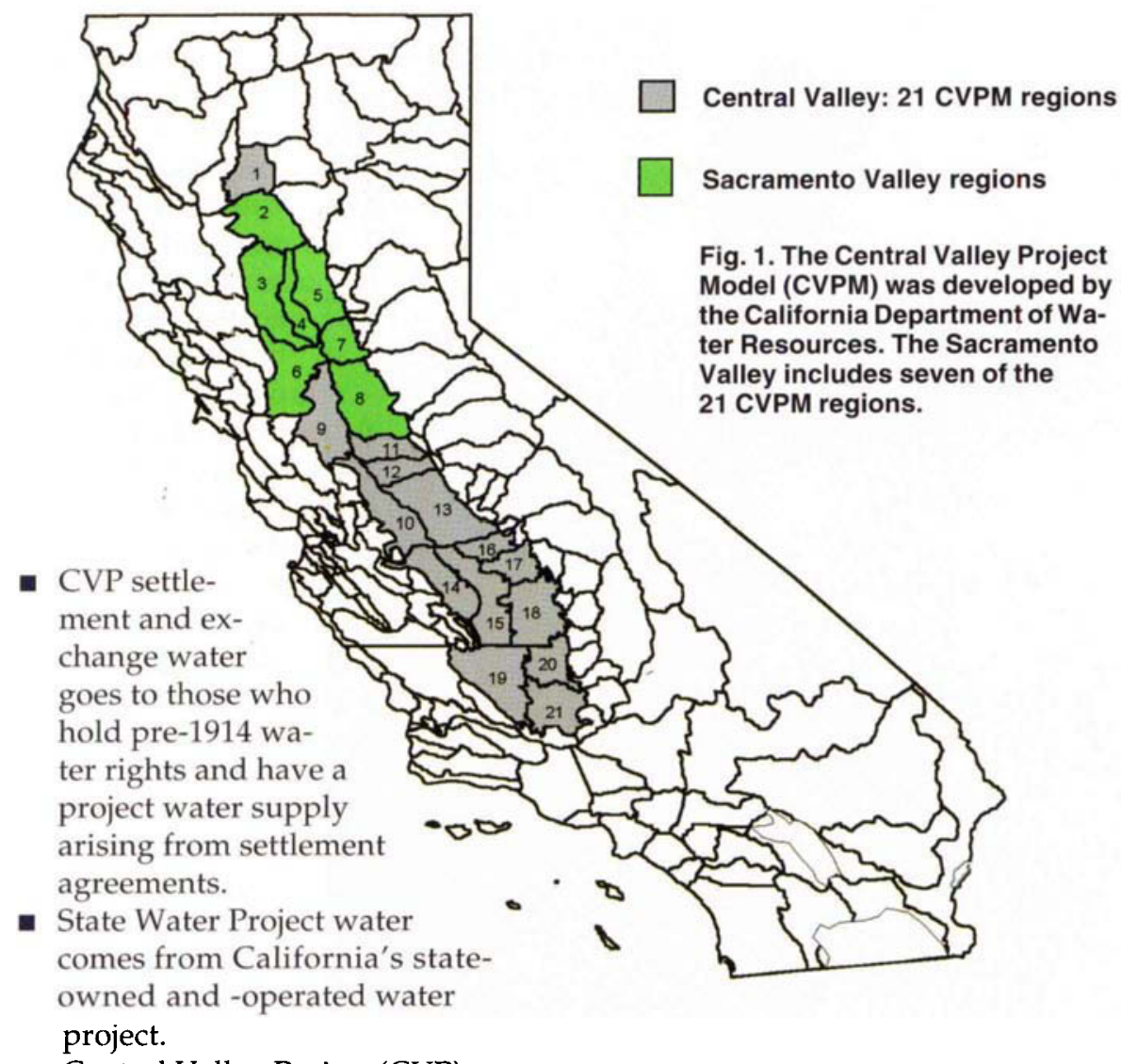

- Central Valley Project (CVP) water is delivered under federal contracts. Valley Project Model (CVPM) that was initially developed by DWR for such analyses (Bureau of Reclamation 1997; DWR 1994).

This model is based on an optimization technique known as positive mathematical programming (PMP). The most important aspect of the PMP technique is that it allows marginal conditions to vary while average conditions calibrate to the base-year data. In other words, PMP uses the observed acreage allocation to derive a net revenue relationship that has a decreasing return per acre as the crop acreage expands in a given region. This decreasing return calculation is based on what we know from experience to be actual returns in this region. Decreasing crop profitability is mostly caused by the decreasing availability of quality land. The model assumes that farmers are fully aware of land effects and that they allocate crops to maximize expected profits from a farm. This changing profitability is contrasted to other optimization models that assume a fixed profitability (Howitt 1995). The model used for our analysis consists of an objective func- 


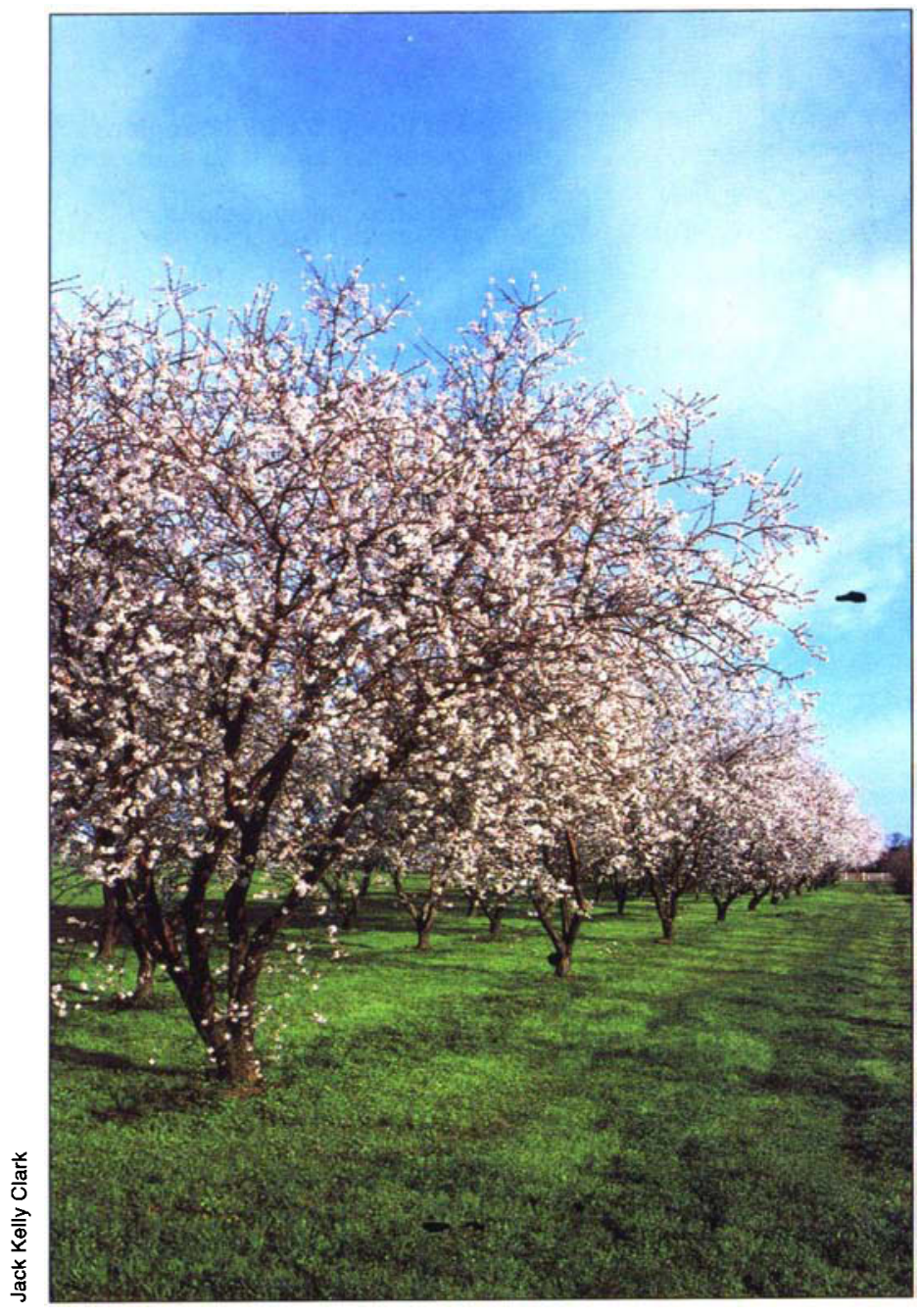

Orchards account for about one-fifth of the crop acreage in the Sacramento Valley, but are not expected to cause major revenue losses following an irrigation water cut.

tion, resource constraints and an irrigation technology equation.

The objective function maximizes the sum of net producer revenue and net consumer benefits. Net revenue is defined as total sales revenue minus irrigation costs and other variable costs. Resource constraints consist of two sets, constraints on total irrigation water available and constraints on total cropland available. A variety of crops are aggregated into 10 categories (table 2). Because of their dominance and economic importance, individual crops such as rice and tomatoes are separated out as individual categories.

Water transfers. The model allows water transfers within a region, but allows no transfer across the region boundary. These regions are relatively homogeneous, but may include several water districts and parts of more than one county. In reality, water is in general not fully transferable within a local region and may be partly transferable across regional boundaries. While our two assumptions on transferability may be offsetting, we think the economic impacts may be underestimated slightly due to our configuration of a region that encompasses many water districts. Water trading is also an important assumption. Zilberman et al. (1994) examined the economic impact of water cuts in the Central Valley under the scenario of water trading and showed that the economic loss due to a water cut can be reduced more than $50 \%$.

Efficiency improvements. The analysis allows for the fact that farmers can adjust to a water shortage by increasing efficiency of their irrigation systems but only at a significant cost. Irrigation systems in the Sacramento Valley have been steadily improved in recent years, and the model assumes that additional gains are possible and would be made if water were even more scarce. In our model, farmers respond to the water cut by adjusting irrigation-systems costs and associated applied water or irrigation efficiency. However, these two water-associated inputs are related through a technical constraint, a constant elasticity of substitution isoquant that governs the trade-offs between system costs and water efficiency. Subject to this constraint, farmers choose water-related inputs (along with other inputs) to maximize their profits.
Prices. Output and input prices are treated as constants. Possible price effects of changes in crop output resulting from the $25 \%$ cut in water supply are not included (they are expected to be quite small). For example, even though the study area produces much of the national output of japonica rice, projected effects on global and local rice prices are expected to be small because supply shifts are limited to only $1 \%$ or $2 \%$. The consequence of the constant price assumption in our application is that net consumer effects are quite small.

CVPM regions. The CVPM is based on geographical units, called CVPM regions, that are configured by DWR in accordance with water distribution channels and the construction of DWR's water data. The Sacramento Valley includes:

- Region 2, Far North (mostly Tehama County).

- Region 3, Northwest (mostly Glenn and Colusa counties).

- Region 4, Sacramento River (mostly the river areas of Colusa and Sutter counties).

- Region 5, Northeast (Butte and Sutter counties and part of Yuba County).

- Region 6, Yolo-Solano (Yolo and Solano counties).

- Region 7, Southeast (northern Sacramento County and southwest Placer and Yuba counties).

- Region 8: Sacramento-San Joaquin (most of Sacramento County and northern San Joaquin County).

Scenario. In our model, we hypothesize the following water-reduction scenario. Surface water (including CVP, state and local water) is reduced by $25 \%$, but this reduction is accompanied by an increase in groundwater use by a maximum of $10 \%$ from 1992 levels. We chose 1992 as a base year because (1) cuts in irrigation water represent policy options that may be more likely considered and adopted during the drought periods, and (2) 1992 represents the most recent drought year. One reaction to a surfacewater cut may initially be increased use of groundwater. However, avail- 
ability of groundwater for further pumping is limited. In order to reflect this situation, the scenario allows the additional supply of groundwater but is limited to a maximum of $10 \%$. We believe our $10 \%$ assumption is reasonable, but it may exclude the situation that prevails under a severe extended drought (table 1). To reflect the sensitivity of the model results to the different reference periods, our original research (Lee et al. 1999) considers an alternative base period. Altering the base period causes no major changes in results.

\section{Model responses to reductions}

In our model, each region responds to the surface-water cut in an optimal way depending on its water situation and pattern of agriculture. In general, there are three ways that a farmer can respond. First, the farmer can alter the crop mix, toward a higher proportion of less water-intensive crops or higher value crops. Second, the farmer can apply less water. Third, the farmer can make an investment in technology that improves water efficiency (indicated by positive water-systems costs). These responses are all aimed at minimizing the reduction in farm net income resulting from the irrigation water cut. Our model allows all three options and finds a combination of responses that minimizes the net income loss (Bureau of Reclamation 1997).

Table 2 presents our model results on the changes in acreage under the $25 \%$ water-cut scenario. Some effects are dramatic. In the Northwest region, irrigated pastureland falls by $27 \%$.

There are also cases where acreage increases. In most regions and for most crops, a cut in irrigation water causes an acreage reduction of up to $3 \%$. However, this rate of reduction seems to be relatively modest, given the $13.6 \%$ water cut (table 1 ). Farmers are, therefore, likely to respond to a water cut mainly by adjusting their cropping patterns, rather than retiring acreage. Among all crops, pastureland has the largest proportional acreage cut. Crops such as vegetables and orchard crops, with high value per unit of water, experience little acreage reduction. Furthermore, increases in area planted tend to occur more often with field crops and small grains that require relatively little water. These adjustments are consistent with profit maximization. When there is a constraint placed on input, in this case water, production tends to shift from more water-intensive crops to less waterintensive crops.

Our model also allows for an adjustment of irrigation systems. As surface water becomes scarce, farmers improve irrigation systems, increase water efficiency and apply less irrigation water (table 3).

For most crops, the optimal input mix is higher systems costs with lower water applications. Among all crops, rice shows the largest proportional increase in water-systems costs, simultaneously with the substantial cut in applied water per acre. The impact of the surface-water reduction depends on the region's groundwater availability. As expected, improvement in irriga- tion systems is more pronounced in regions $3,4,5$ and 7 where surface water is a more important source than groundwater, while smaller adjustments are realized in regions that rely more heavily on groundwater. The Far North and Sacramento-San Joaquin regions rely heavily on groundwater in their irrigation water supplies (table 1). This implies that the effect of the $25 \%$ surface-water cut in these regions is relatively small and we may expect smaller impacts on agriculture than in other regions (table 3 ).

We do not present regional farmrevenue for effects by crop here, but the major revenue loss in most counties occurs with rice; the Northwest region loses $\$ 4.2$ million of rice revenue, and regions 4, 5 and 6 also experience large losses. As expected, vegetable, fruit and nut revenues are harmed the least by the surface-water cut across regions, and in some cases revenues actually increased for these crops.

TABLE 3. Percent changes in water-related variables in response to a $25 \%$ cut in surface-water availability*

\begin{tabular}{|c|c|c|c|c|c|c|c|c|c|c|c|}
\hline & & Pasture & $\begin{array}{c}\text { Alfalfa } \\
\text { hay }\end{array}$ & $\begin{array}{l}\text { Sugar- } \\
\text { beets }\end{array}$ & $\begin{array}{c}\text { Nongrai } \\
\text { field } \\
\text { crops }\end{array}$ & $\begin{array}{l}\text { in } \\
\text { Rice }\end{array}$ & $\begin{array}{l}\text { Vege- } \\
\text { tables }\end{array}$ & Tomatoes & $\begin{array}{l}\text { Fruits } \\
\text { and } \\
\text { nuts }\end{array}$ & $\begin{array}{l}\text { Small } \\
\text { grains }\end{array}$ & $\begin{array}{c}\text { Sub- } \\
\text { tropical } \\
\text { orchards }\end{array}$ \\
\hline & Appl. water & -1.1 & -1.3 & 0.5 & -0.9 & -1.2 & 0.4 & - & -1.1 & -1.4 & -1 \\
\hline Region 2 & IS cost & 2.1 & 2.6 & -1 & 1.7 & 6 & -1 & - & 2.4 & 5.1 & 2.4 \\
\hline \multirow[t]{3}{*}{ Far North } & Water effi. $\dagger$ & $\quad 1.1$ & 1.3 & -0.5 & 0.9 & 1.2 & -0.4 & - & 1.1 & 1.4 & 1.1 \\
\hline & W-rel costs & -0.3 & -0.2 & -0.2 & 0.2 & -0.6 & -0.3 & - & 0.8 & 3.2 & 0.9 \\
\hline & Appl. water & -4.5 & -10.3 & -6.5 & -7.4 & -10.9 & -9.6 & -7.2 & -9 & -6.6 & -8.8 \\
\hline Region 3 & IS cost & 9.4 & 23.9 & 16.1 & 15.8 & 64.3 & 28.2 & 20.4 & 24 & 29.6 & 24.1 \\
\hline \multirow[t]{3}{*}{ Northwest } & Water effi. & 4.7 & 11.4 & 7 & 8 & 12.3 & 10.6 & 7.7 & 9.8 & 7 & 9.7 \\
\hline & W-rel costs & -0.7 & 0.9 & 5.8 & 4 & 3 & 11.6 & 5.8 & 10.1 & 19.7 & 11.2 \\
\hline & Appl. water & -21.9 & -22.4 & -13.1 & -15 & -15.4 & -19.7 & -14.6 & -16 & -5.4 & - \\
\hline Region 4 & IS cost & 64.4 & 67.4 & 41.4 & 41 & 97.6 & 74.4 & 52.9 & 51.2 & 23.2 & - \\
\hline \multirow[t]{3}{*}{ Sac. River } & Water effi. & 28 & 28.8 & 15.1 & 17.7 & 18.2 & 24.5 & 17 & 19 & 5.7 & - \\
\hline & W-rel costs & 17.9 & 24.3 & 26.4 & 22.7 & 8.5 & 48.4 & 30.1 & 34.4 & 18.4 & - \\
\hline & Appl. water & -18 & -17.9 & -10.7 & -11.9 & -15.4 & -15.7 & -11.6 & -14.6 & 0.3 & -14 \\
\hline Region 5 & IS cost & 48.5 & 48.7 & 30.4 & 29.2 & 97.6 & 53.3 & 38.1 & 45 & -1 & 43.7 \\
\hline \multirow[t]{3}{*}{ Northeast } & Water effi. & 21.9 & 21.8 & 11.8 & 13.5 & 18.2 & 18.5 & 13.1 & 17.1 & -0.3 & 16.3 \\
\hline & W-rel costs & 10.4 & 14.5 & 17.9 & 14.5 & 6 & 32.4 & 19.7 & 28.5 & -0.8 & 28.9 \\
\hline & Appl. water & -3.5 & -6 & -3.8 & -4.3 & -6 & -5.5 & -4.2 & -5.2 & -5 & - \\
\hline Region 6 & IS cost & 7.1 & 12.9 & 8.6 & 8.5 & 32.5 & 14.8 & 10.9 & 12.7 & 21.5 & - \\
\hline \multirow{3}{*}{ Yolo-Solano } & Water effi. & 3.6 & 6.4 & 4 & 4.5 & 6.4 & 5.8 & 4.3 & 5.5 & 5.3 & - \\
\hline & W-rel costs & -1.2 & -1 & 2.1 & 1.1 & -2.9 & 4.7 & 1.9 & 4 & 13.4 & - \\
\hline & Appl. water & -9.2 & -10.1 & -6 & -7 & -11.2 & 0.5 & -6.3 & -5.9 & -4.5 & - \\
\hline Region 7 & IS cost & 20.6 & 23.4 & 15 & 14.9 & 62.1 & -1 & 19.2 & 16.4 & 17.1 & - \\
\hline \multirow[t]{3}{*}{ Southeast } & Water effi. & 10.1 & 11.3 & 6.4 & 7.6 & 12.6 & -0.5 & 6.8 & 6.3 & 4.7 & - \\
\hline & W-rel costs & 1 & 2.9 & 7.6 & 6.1 & 0.5 & -0.3 & 9.2 & 11 & 12.5 & - \\
\hline & Appl. water & -0.1 & -0.1 & 0 & 0 & 0.2 & 0.4 & 0 & 0 & -0.3 & - \\
\hline Region 8 & IS cost & 0.2 & 0.1 & 0 & 0 & -1 & -1 & 0 & 0 & 0.9 & - \\
\hline \multirow[t]{2}{*}{ Sac-S.J. } & Water effi. & 0.1 & 0.1 & 0 & 0 & -0.2 & -0.4 & 0 & 0 & 0.3 & - \\
\hline & W-rel costs & -0.1 & 0 & 0 & 0 & 0.1 & -0.3 & 0 & 0 & 0.5 & - \\
\hline
\end{tabular}

For each region, the values reported are \% changes in applied water (appl. water), irrigation-systems costs (IS cost), water efficiency (water effi.) and water-related costs (w-rel costs).

†Measured as a ratio of evapotranspiration to applied water per acre. 
Across our core area, regions 2

through 5, the major losses were seen in rice, field crops and pastureland.

Overall crop-revenue losses for these core regions amount to $\$ 8 \mathrm{mil}$ lion while the loss for the entire Sacramento Valley is $\$ 11$ million. More than three-quarters of total revenue losses occur in rice. The loss in farm revenue is mitigated by the adjustments farmers and others make in response to surface-water reductions. Importantly, water is moved to its highest valued use and water-use efficiency is improved to maximize net farm revenue. The result is a smaller percentage decline in farm revenue than the $25 \%$ cut in surface water. Finally, it is worth noting that farmland values are closely tied to net revenue changes from production. Even though further discussion on farmland value is beyond our scope, with relatively active land markets, land prices should move together in proportion to changes in the net income stream.

\section{Economic impacts}

We now broaden our focus from the agricultural sector to the overall economy by examining how the declines in farm revenue may trigger a further decline in revenue in the Sacramento Valley. We quantitatively evaluate the effects of a cut in irriga- tion water on the overall local (county) revenue as well as the effects on the local job market using income and job multipliers.

The economic assessment is made at the county level by first allocating regional agricultural effects across counties. The conversion from region to county is based on crop acreage, with a region's acreage being distributed among the counties of which it is comprised. We developed conversion acreage formulas from region to county based on acreage data collected by California Agricultural Statistics Service, other crop maps, and county agricultural commissioner reports. (Actual conversion formulas are provided in Lee et al. 1999.)

Revenue effects include revenue generated (or foregone) over the entire local economy due to agricultural revenue changes that are measured at the farm-gate level. This includes revenue from packing and shipping, brokerage, and retail activities as well as farm-input-industry activities. Multiplier effects differ across crops, depending on the extent of postharvest activities and whether or not the product is processed. For example, fresh produce such as fruits and vegetables has relatively large income multipliers compared to feed grains such as corn and wheat, because fresh produce re- quires additional local packing and shipping. Activities that take place outside the county are not included in our multiplier impacts. For example, economic activity generated from crop output in another county is not shown in the revenue totals used here. This suggests that the overall multiplier effect in the Sacramento Valley is likely to be larger than our estimates.

We used income multipliers developed by Goldman at UC Berkeley (Carter and Goldman 1992). The multipliers are specific to crops and counties, and take into account various offfarm activities for each crop category as well as the scale of other activities in each county. They range from 1.2 to 2.5 , meaning that a $\$ 1.00$ change in farm-gate revenue results in a $\$ 1.20$ to $\$ 2.50$ revenue change in the overall county economy. Fruits have the highest multiplier among all crop categories. Sacramento County tends to have the highest multipliers across almost all crop categories, which may be due to its large economy as compared to other counties and the fact that many farm-related activities occur there.

As expected, aggregate county revenue effects are generally negative (table 4). Under all scenarios, the smallest revenue loss occurs in Tehama County, and the largest occurs in Colusa County, which alone makes up almost $32 \%$ of the total revenue loss for the Sacramento Valley. Glenn and Yolo counties also experience substantial revenue losses. Revenues from waterintensive crops such as rice, pasture and alfalfa, are reduced by a substantial margin.

Revenue from rice decreases the most, accounting for almost $90 \%$ of total revenue losses. This occurs in part because rice tends to be particularly dependent on surface water and be- 
cause it is the most important crop in most counties. Rice revenues have the largest share of revenue in Butte,

Colusa, Glenn, Sutter and Yuba counties. However, the $90 \%$ share is a very high ratio given that rice contributes only $16 \%$ of total crop revenue in the Sacramento Valley. This implies that a reduction in surface irrigation water affects rice production much more severely than other crops, and the economic impact would be greater in counties that have more intense rice production (table 4).

The major rice-growing counties of Colusa and Glenn are the hardest hit. However, Yolo County is not among the major rice-producing counties but its total revenue losses are almost as high as in Glenn County. This is because Yolo County has high total crop revenue compared to other counties. Unlike other counties, Yolo County's losses are spread among various crops. Lee et al. (1999) demonstrate that effects are much larger where the percentage water cut is from a "normal" year base and when groundwater substitution does not occur. In the most extreme scenario, the water cut would cost $\$ 46$ million in total revenue and more than 300 jobs across the eight counties. Again the losses are largest in Colusa and Glenn counties. The largest revenue loss in Colusa County among all scenarios is more than $5 \%$ of the county personal income.

To illustrate what the revenue losses mean more broadly, the total revenue effect for each county is calculated as a percentage of the county personal income (data not shown'). Colusa County is the hardest hit, not only by losing the largest amount of revenue, but also by losing the largest percentage $(1.6 \%)$ of personal income. The next hardest hit was Glenn County $(1.08 \%)$. These two counties have the lowest personal income among all Sacramento Valley counties, as well as the highest economic reliance on agriculture. (The ratios of the value of agricultural production to county personal income are 0.54 for Colusa County and 0.46 for Glenn County.) For the remaining counties, total revenue effects are less than $1 \%$ of county personal income.

\section{Agriculture, water and economies}

Each of the counties we examined has a large agricultural industry. Except for Sacramento and Yolo counties, farming itself primarily irrigated agriculture - is the dominant contributor to the local economy. The importance of agriculture as a primary industry in this region underscores the importance of irrigation water supply. Results of this study indicate at least three general conclusions.

Adjustments that occur within the agricultural production system in response to reduced water supply are crucial. These adjustments are generally found by (1) substituting away from intensive water use by adopting more efficient irrigation technologies, and (2) switching to crops that use less water or earn more dollars per unit of water. Our results show that farmers tend to switch away from water-intensive crops such as rice, pastureland or alfalfa to less water-intensive crops such as small grains.

A reduction in water supply results in relatively greater economic impacts on those counties that are more dependent on agriculture. As expected, revenue losses are highest in absolute and relative terms for those counties with more agricultural output. Colusa County is one of the most reliant on agriculture in its economy (and on irrigation from surface-water sources); therefore, its economy loses the largest overall amount of revenue as well as
Yolo County receives more than half of its crop revenue from vegetables, primarily processing tomatoes, above. Orchard crops such as stone fruits, olives, walnuts and almonds, below, are among the most important crops in the Sacramento Valley.

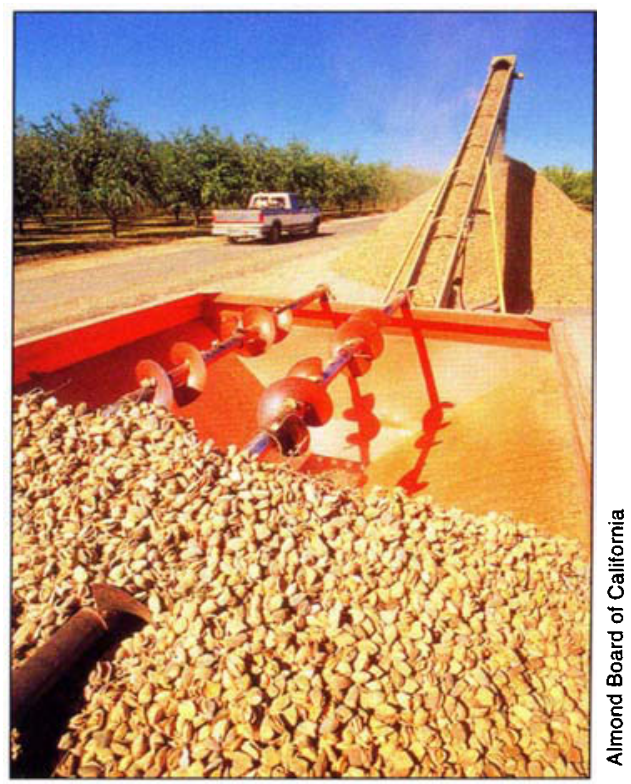




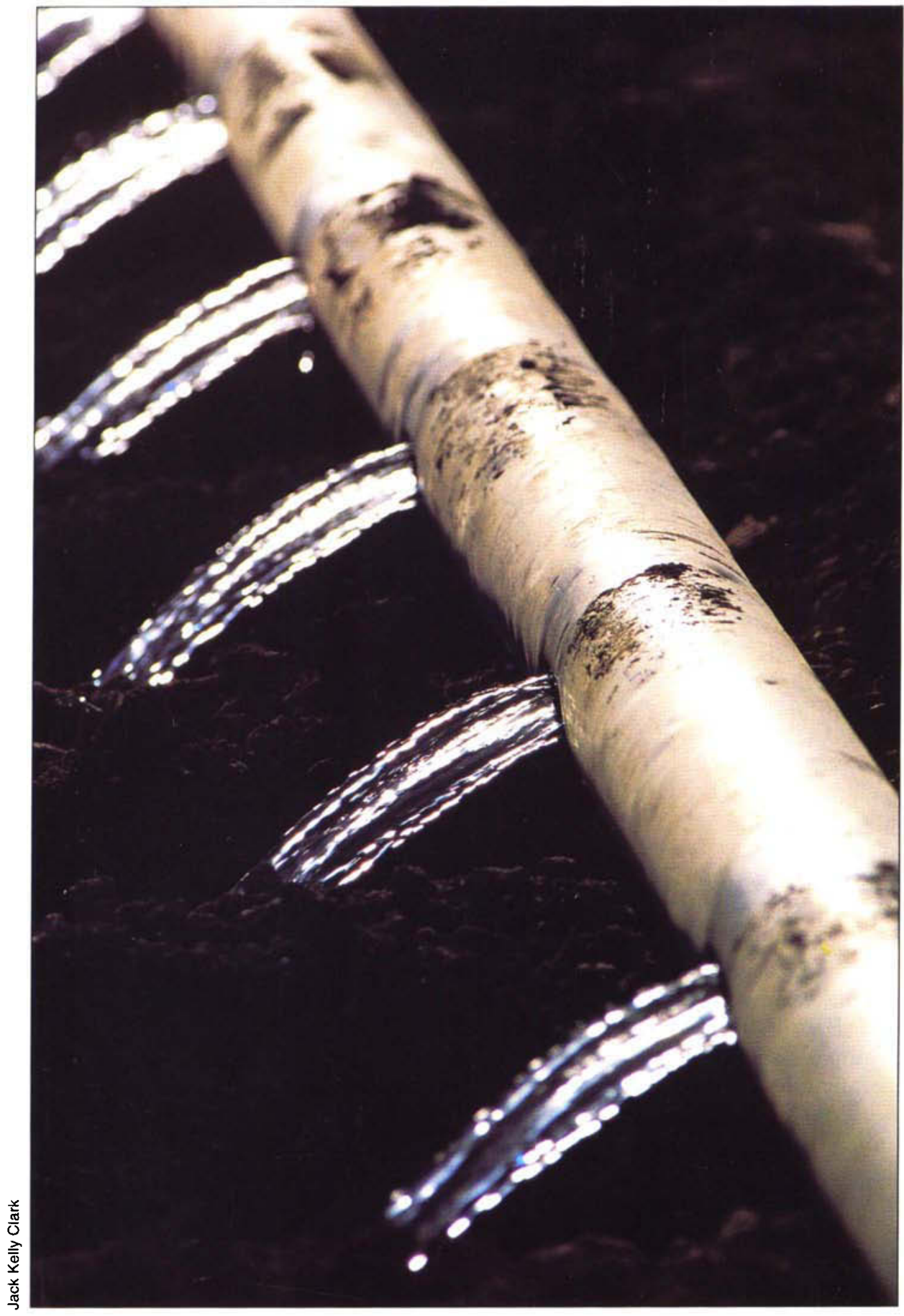

Growers would adjust to a loss of irrigation water by adopting more efficient technologies and switching to less waterintensive crops.

the largest percentage of personal income, exceeding $\$ 5$ million per year, or about $1.6 \%$. The next hardest hit is Glenn County, at about $1 \%$ of county personal income; Glenn County is next to Colusa County in its reliance on agriculture in its economy.

Counties that depend heavily on agriculture for their economic livelihoods are also the poorest in the Sacramento Valley. All of the counties that have large agricultural industries tend to have lowest per capita personal incomes. This suggests that the counties with the least economic resources would be hardest hit if the water supply were reduced.

H. Lee is Research Economist, D. Sumner and $R$. Howitt are Professors, Department of Agricultural and Resource Economics, UC Davis.

\section{References}

Bureau of Reclamation. 1997. Central Valley Project Improvement Act: Technical Appendix, Vol 8. US Department of Interior, September.

Carter H, Goldman G. 1992. The Measure of California Agriculture. UC DANR November. $62 \mathrm{p}$.

[DWR] California Department of Water Resources. 1994. California Water Plan Update, Bulletin 160-93, October. http:// rubicon.water.ca.gov/

Howitt R. 1995. Positive mathematical programming. Am J Ag Econ 77(May):1-14

Lee H, Sumner D, Howitt R. 1999. Economic Impacts of Irrigation Water Cuts in the Sacramento Valley. UC Agricultural Issues Center. 62 p. http://aic.ucdavis.edu/pub/ list.htmi

Zilberman D, Sunding D, Howitt $R$, et al. 1994. Water for California agriculture. Choices 4:25-8.

\section{CALIFORNIA AGRICULTURE ASSOCIATE EDITORS}

Animal, Avian, Aquaculture \& Veterinary Sciences Jim Cullor

Christopher M. Dewees

Kathryn Radke

Barbara A. Reed

Economics \& Public Policy

George Goldman

Richard A. Howitt

Alvin Sokolow

Food \& Nutrition

Amy Block Joy

Sheri Zidenberg-Cherr http://danr.ucop.edu/calag/

CALAG@ucop.edu

PH: 510 987-0044

FAX: $510465-2659$

\section{Development}

Linda M. Manton

Land, Air \& Water Sciences

Mark Grismer

John Letey

Henry J. Vaux, Jr.

Natural Resources

Daniel W. Anderson

Lynn Huntsinger

Richard B. Standiford
Pest Management

Michael K. Rust

Robert Washino

Plant Sciences

Jodie S. Holt

Lee F. Jackson

G. Steven Sibbett 